\title{
クリギング法を用いた建物ごと APPLICATION OF KRIGING の地震ハザード推定の実用化 METHOD TO ESTIMATIONS OF SEISMIC HAZARDS FOR EACH CONSTRUCTION SITE
}

\section{菅井径世— -1 水谷由香里 — $* 2$ \\ 森 保宏——3 \\ キーワード : \\ クリギング解析，実用化，精度，定量性，客観性}

Keywords:

Kriging Analysis, Practical Application, Accuracy, Quantitativity, Objectivity

\section{Michiyo SUGAI — $* 1 \quad$ Yukari MIZUTANI- $* 2$ Yasuhiro MORI — $* 3$}

The present paper reports some results of the investigation of practical application of an advanced Kriging method proposed by the authors to estimate seismic hazards. By adding only one new parameter, the proposed method can provide AIC 120 to 250 lower than that by an ordinary Kriging method, which corresponds to the random fields with 60 to 120 fewer explanatory variables. Also, the proposed method estimates the ranges of 150 to $700 \mathrm{~m}$ while an ordinary method calculates those of 30 to $80 \mathrm{~m}$. As a result, the proposed method can practically estimate seismic hazards accurately for each construction site.

的な地盤に対する評価の一つの代表事例と考えることができる。

著者らは, 文献 1)において, ボーリング地点における地表での地 震動パラメタ（計測地震動, 最大加速度, PL 值など）を元に, 最も 汎用的な空間統計解析法の一つであるクリギング法を拡張適用し, 標本点における評価誤差を考慮することによって，任意の建設サイ トにおける地震動パラメタを推定する方法を提案した。この方法に よれば，スプライン補間法や逆距離加重法などの決定論的な平滑化 方法などでは表現できない確率場モデル現象の再現が可能となり， 空間的な推定精度も定量的に評価できる。また， $250 \mathrm{~m}$ などのメッ シュ単位で, 工学的判断に基づく地盤モデルの作成も必要としない ため，計算時間を大幅に削減でき，したがって，建物ごとの詳細な 地震八ザードマップを，低コストで提供することが可能となる。し かしながら，工学的観点からは，理論上の利点に対する評価のみで は充分とは結論とし難く，1 つの新技術としての評価を得るには， 実務利用した結果を持って, その妥当性, 有用性を検証することが 重要である。

愛知県尾張旭市では, 平成 26 年度事業において, 著者らが提案し た手法に基づいて，地震八ザードマップおよびリスクマップを作成 しており, 計測地震動および液状化マップに関しては, 既に市の公 式ホームページ上に公開し ${ }^{2)}$ ，その一部は，印刷物として市内の各 戸へ配布している。本稿は, 尾張旭市における地震八ザード評価に おいて, 著者らが提案した方法で推定したクリギングの統計解析結 果と標本点における評価誤差を考慮しない一般的なクリギング法に よるそれを比較しながら提示し，提案法の妥当性，有用性について 報告するものである。

尾張旭市は, わが国の人口の多くが集住する広域平野の代表例で ある濃尾平野の東部に位置しており，ここでの手法の評価は，一般

\section{2. クリギング法の定式化}

\section{1 基礎的な定式化}

クリギング法により空間データ予測を行う場合，通常，確率場モ デルの共分散行列を規定するバリオグラム関数と空間内の全体的な 傾向を表すトレンド関数を同定することが最も重要な解析作業とな る $\left.{ }^{3)}, 4\right)$ 。地震動の空間分布に関する確率場モデル（バリオグラム関 数とトレンド関数）は，次式に示す一般的な最尤法に基づく赤池統 計量 $\mathrm{AIC}^{5)}$ を最小化する基準によって同定することができる。

$$
\min _{\boldsymbol{\mu}, \boldsymbol{\theta}, m} \mathrm{AIC}=-2 \times \operatorname{Max}\{\ln p(\mathbf{z} \mid \boldsymbol{\mu}, \boldsymbol{\theta})\}+2 \times(m)
$$

ここで, $m$ は式中の確率場の説明変数の数, 変量ベクトル $\mathbf{z}$ は, 解 析対象地域内の観測点 $i$ で得られる地震動パラメ夕 $z_{i}$ で構成される ベクトルである。また, $p(\mathbf{z} \mid \cdot)$ は, $\mathbf{z}$ の多変量同時確率密度関数で あり, $p(\mathbf{z} \mid \cdot)$ が正規分布の場合，次式のように表される。

$$
p(\mathbf{z} \mid \boldsymbol{\mu}, \boldsymbol{\theta})=\left(\frac{1}{\sqrt{2 \pi}}\right)^{\frac{n}{2}}|\mathbf{C}|^{-\frac{1}{2}} \exp \left\{-\frac{1}{2}(\mathbf{z}-\boldsymbol{\mu})^{T} \mathbf{C}^{-1}(\mathbf{z}-\boldsymbol{\mu})\right\}
$$

ここに， $\boldsymbol{\mu}$ はクリギング法におけるトレンド関数によって定まる平 均值ベクトルであり，トレンド関数 $\mu$ は $\mathbf{z}$ の観測点の位置 $\mathbf{u}$ によっ て定まる。以下， $\boldsymbol{\mu}$ をトレンドベクトルと呼ぶ。また， $\mathrm{C}$ は，説明 変数 $\boldsymbol{\theta}$ によって定まる $\mathrm{z}$ の共分散行列である。 $\mathrm{C}$ を構成する要素 $C\left(\mathbf{u}_{i}, \mathbf{u}_{j}\right)$ は，2 2 つ地点 $\mathbf{u}_{i}$ と $\mathbf{u}_{j}$ 間の距離 $h$ のみに依存する共分散関数 であり, 尾張旭市における実用化事例では, 次式の一般的な指数型 モデルを用いている。

\footnotetext{
名古屋産業大学大学院環境マネジメント研究科 教授・工博

名古屋大学大学院環境学研究科 大学院生

( ₹ 464-8601 愛知県名古屋市千種区不老町)

名古屋大学大学院環境学研究科 教授・Ph.D.
} 


$$
C\left(\mathbf{u}_{i}, \mathbf{u}_{j}\right)=C(h)=\sigma^{2} \exp \left(-\frac{h}{\ell}\right)
$$

ここに,

$$
\ell>0, h=|\mathbf{h}|=\left|\mathbf{u}_{i}-\mathbf{u}_{j}\right| \geq 0
$$

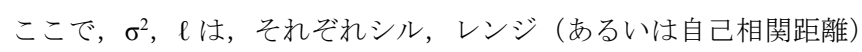
と呼ばれるパラメタである。

一般に, $C\left(\mathbf{u}_{i}, \mathbf{u}_{j}\right)$ とバリオグラム関数 $\gamma\left(\mathbf{u}_{i}, \mathbf{u}_{j}\right)$ との関係は次式のよう に表される。

$$
C\left(\mathbf{u}_{i}, \mathbf{u}_{j}\right)=C(h)=\sigma^{2} \exp \left(-\frac{h}{\ell}\right)=C(0)-\gamma(h)
$$

すなわち, 指数型モデルの $\gamma\left(\mathbf{u}_{i}, \mathbf{u}_{j}\right)$ は次式によって表される。

$$
\gamma\left(\mathbf{u}_{i}, \mathbf{u}_{j}\right)=\gamma(h)=\sigma^{2}\left\{1-\exp \left(-\frac{h}{\ell}\right)\right\}
$$

$\mathbf{u}_{i}$ と $\mathbf{u}_{j}$ の 2 地点間の距離 $h$ は既知であり, $\mathbf{C}$ は $\gamma$ によって規定され るので, $\mathbf{C}$ のすべての要素は $\sigma^{2}$ とによって定まる。すなわち,一 般に $\mathbf{C}$ に関する説明変数の数 $m_{c}$ は 2 である。

$\boldsymbol{\mu}$ の要素 $\mu_{i}=\mu\left(\mathbf{u}_{i}\right)$ は, 位置による関数であり, 解析するパラメタ の物理的特性から推定される空間的分布モデルによって, 三角関数 や指数関数などを利用して表すこともできるが，尾張旭市における 実用化事例では, 次式に示すような, 地点 $i$ の位置 $\mathbf{u}_{\mathrm{i}}$ の平面座標 $\left(x_{i}, y_{i}\right)$ による $n_{t}$ 次元の位置関数ベクトル $\mathbf{f}\left(\mathbf{u}_{i}\right)$ と係数ベクトル $\mathbf{b}$ の積による 多項式を利用している7。

$$
\begin{aligned}
\mu\left(\mathbf{u}_{i}\right)= & \mathbf{b} \cdot \mathbf{f}\left(\mathbf{u}_{i}\right)=\sum_{k=0}^{m_{t}-1} b_{k} f_{k}\left(\mathbf{u}_{i}\right)=\sum_{k=0}^{m_{t}-1} b_{k} f_{k}\left(x_{i}, y_{i}\right) \\
= & b_{0}+b_{1} x_{i}+b_{2} y_{i}+b_{3} x_{i}^{2}+b_{4} x_{i} y_{i}+b_{5} y_{i}^{2}+\cdots \\
& +b_{m_{t}-2} x_{i} y_{i}^{n_{t}-1}+b_{m_{t}-1} y_{i}^{n_{t}}
\end{aligned}
$$

ここに，

$$
\begin{aligned}
\mathbf{f}\left(\mathbf{u}_{i}\right) & =\left\{f_{0}\left(\mathbf{u}_{i}\right), \ldots, f_{m_{t}-1}\left(\mathbf{u}_{i}\right)\right\}^{T} \\
& =\left(1, x_{i}, y_{i}, x_{i}^{2}, x_{i} y_{i}, y_{i}^{2}, \cdots, x_{i} y_{i}^{n_{t}-1}, y_{i}^{n_{t}}\right)^{T}
\end{aligned}
$$

また，

$$
\mathbf{b}=\left(b_{0}, b_{1}, b_{2}, b_{3}, b_{4}, b_{5}, \cdots, b_{m_{t}-2}, b_{m_{t}-1}\right)
$$

ここで, 次元 $n_{t}$ と $\mathbf{b}$ の要素数 $m_{t}$ の関係は次式によって表される。

$$
m_{t}=\frac{\left(n_{t}+1\right)\left(n_{t}+2\right)}{2}
$$

式(1)中の $m$ は, $\boldsymbol{\mu}$ を定めるパラメタの数 $m_{t}$ と $\mathbf{C}$ の説明変数 $\boldsymbol{\theta}$ を 定めるパラメタの数 $m_{c}$ の和 $\left(m=m_{c}+m_{t}\right)$ である。当然のことなが ら, $m$ を増やせば, $\mathbf{z}$ の挙動を表す確率密度関数による最大対数最 尤值は大きくなるが, 式(1)を基準とする時, 最大対数最尤值を大き くしても $m$ が増えれば AIC の值は必ずしも小さくならない。 $\mathbf{z}$ にど のようなモデルを用い, $m$ をいくつとすべきかは, 情報量統計の立 場から，式(1)にもって客観的に判断することができる。

\section{2 提案法と一般的なクリギング手法}

一般的なクリギング解析の場合, $\mathrm{z}$ は確率場における実現值であ
ると考える。ところが, ボーリング調査地点で得られる標本には推 定誤差が付帯することから, 著者らは, $\mathbf{z}$ の要素 $\mathrm{z}_{i}$ の計算誤差 $\sigma_{i}$ (以 下, 計算誤差標準偏差と呼ぶ（観測誤差と呼ばれることもある $\left.{ }^{6}\right)$ ) の数学モデルとして, 次式のように式(2)中の共分散行列 $\mathbf{C}$ の対角項 に, 計算誤差分散 $\sigma_{i}{ }^{2}$ を加えた $\mathbf{C}$ 'を共分散行列として, $p(\mathbf{z} \mid \cdot)$ を推 定する方法を提案した ${ }^{1}$ 。

$$
\mathbf{C}^{\prime}=\left[\begin{array}{cccc}
C\left(\mathbf{u}_{1}, \mathbf{u}_{1}\right)+\sigma_{1}^{2} & C\left(\mathbf{u}_{1}, \mathbf{u}_{2}\right) & \cdots & C\left(\mathbf{u}_{1}, \mathbf{u}_{n}\right) \\
C\left(\mathbf{u}_{2}, \mathbf{u}_{1}\right) & C\left(\mathbf{u}_{2}, \mathbf{u}_{2}\right)+\sigma_{2}^{2} & \cdots & C\left(\mathbf{u}_{2}, \mathbf{u}_{n}\right) \\
\vdots & \vdots & \ddots & \vdots \\
C\left(\mathbf{u}_{n}, \mathbf{u}_{1}\right) & C\left(\mathbf{u}_{n}, \mathbf{u}_{2}\right) & \cdots & C\left(\mathbf{u}_{n}, \mathbf{u}_{n}\right)+\sigma_{n}^{2}
\end{array}\right]
$$

尾張旭市のハザード評価では, $\sigma_{i}{ }^{2}=\sigma_{c}{ }^{2}(i=1, \ldots, n)$ とした。このとき $\mathbf{C}^{\prime}$ の説明変数の数 $m_{c}$ は, $\mathbf{C}$ の説明変数 $\sigma^{2}$ と $\ell$ に, もう 1 つの説明 変数 $\sigma_{c}{ }^{2}$ を加えるので 3 となる。

\section{3. 計測震度の推定}

\section{1 パラメタと計算条件など}

尾張旭市が八ザード評価において想定した地震は, これらは, 尾 張旭市が先に独自に被害想定を実施した猿投一高浜断層帯地震（以 下, 高浜一猿投地震と呼ぶ）, 愛知県が想定した東海・東南海連動 地震 (以下, 2 連動地震と呼ぶ), 国が想定した東海・東南海・南海 三連動地震 (尾張旭市が愛知県を通じて入手したもの, 以下, 3 連 動地震と呼ぶ), および愛知県が内閣府の検討を基に想定した南海卜 ラフを震源とする 3 種の南海トラフ巨大地震 ${ }^{8)}$ である「過去最大」,

「理論最大・東側」, 「理論最大・陸側」（以下，それぞれ過去最 大地震, 東側地震, 陸側地震と呼ぶ) の 6 種である。

利用したボーリングデータの数は, 尾張旭市が平成 25 年度事業に おいて独自に収集し整理した市内の 676 本と, 周辺の市などから提 供を受けた 72 本を合わせた 748 本である。市内のみでなく, 市の周 辺のデータを用いることにより，隣接する市との境界近辺でもより 精度の高い補間計算が可能になる。

愛知県などからは, 尾張旭市を覆う $250 \mathrm{~m}$ などのメッシュ毎に工 学基盤上で計算された地震波形が提供された。これを, 各メッシュ の中心点における工学基盤上での地震波と仮定し, 各ボーリング地 点における工学基盤上での地震波は, フーリエパワースペクトルに ついては最も近い 4 つのメッシュの中心点での地震波のフーリエパ ワースペクトルを距離の逆数の 2 乗で加重平均して, 位相について は最も近接する中心点の位相を用いて計算し, これを利用した。な お, ボーリング地点の工学基盤における地震波は, 尾張旭市内では 大きな変動や差はなかった。

尾張旭市は, ボーリング地点における表層の地震波を, 修正 R-O モデルを用いた非線形解析によって計算した。続いて, 地震動パラ メタとして, 最大加速度 (PGA), 最大速度 (PGV), 最大変位 (PGD), 計測震度, SI 值, PL 值, 沈下量の 6 つを計算した。以下に, 市の 計算結果を用いた提案法による統計解析結果を示す。なお, 紙面の 都合上, 計測震度の検討結果のみを報告する。

\section{2 比較計算の方法}

次節以降では, 式(11)において $\sigma_{c}^{2}$ を未知パラメタとして $\gamma$ を求め た場合（ケース A）と, $\sigma_{c}{ }^{2}=0$, すなわち, 一般的なクリギング解析 


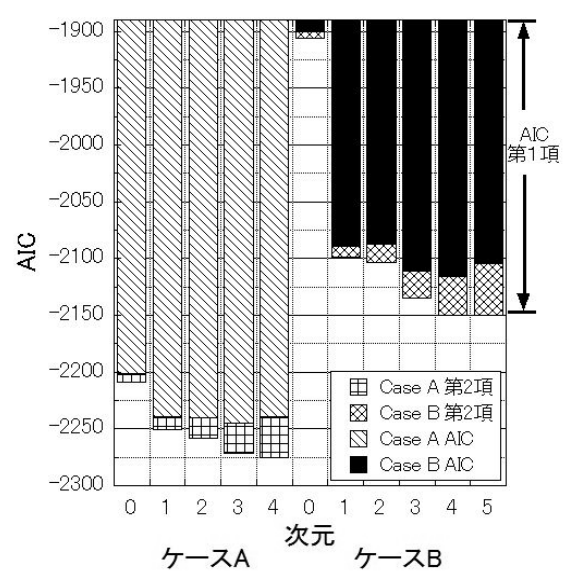

(1) 高浜一猿投地震

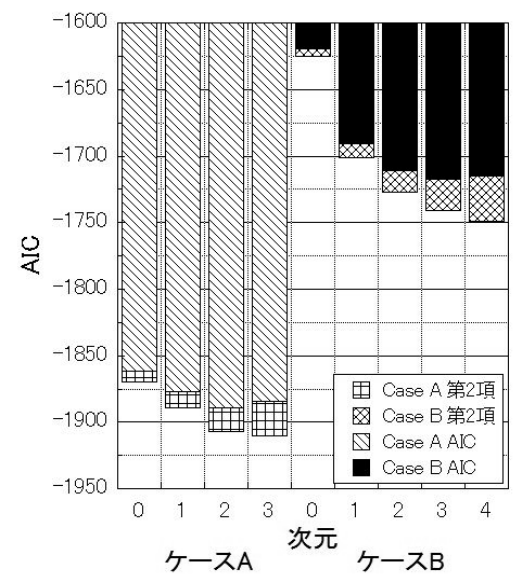

(4) 過去最大地震

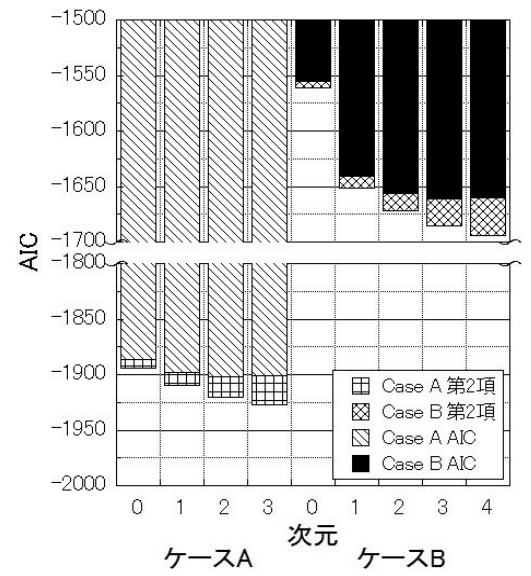

(2) 2 連動地震

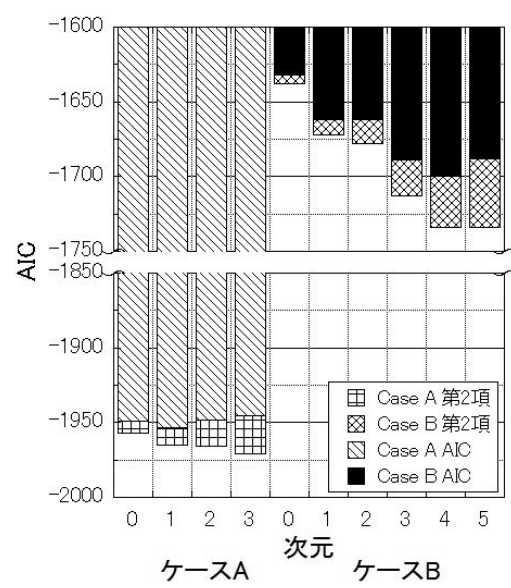

(5) 東側地震

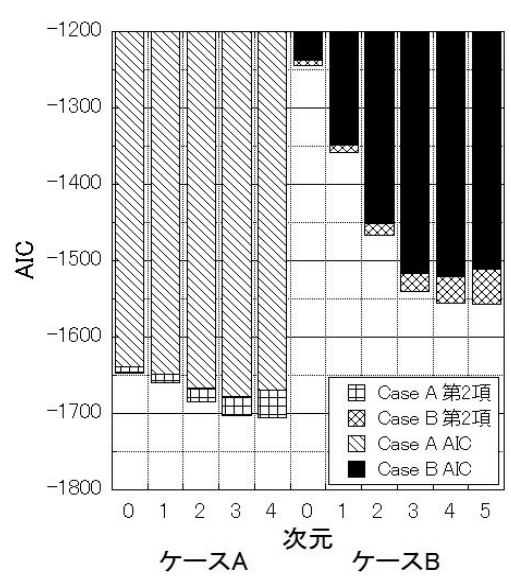

（3） 3 連動地震

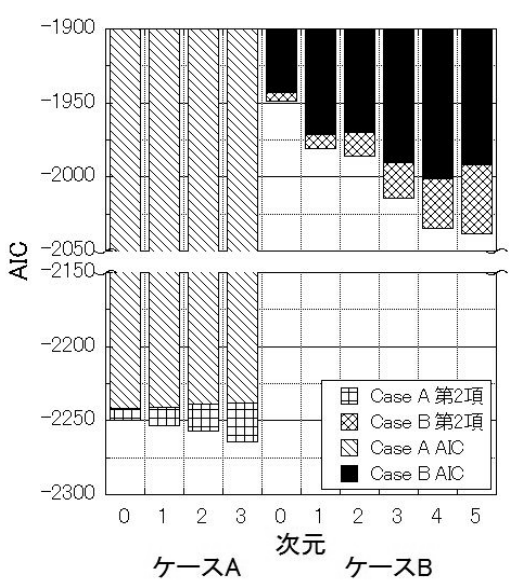

(6) 陸側地震

図 1 尾張旭市における各種震源に対する赤池統計基準の計算結果

で $\gamma$ を求める際に「 $\mathbf{z}$ は誤差のない実現值」であると仮定した場合 (ケース B) について, 式(1)によって計算した AIC および $\gamma$ に関す る解析結果を比較検討する。

ケース A， B どちらの場合も，式(7)のトレンド関数の次元が大き くなると, 式(1)の第 1 項は小さくなる一方, 第 2 項は大きくなる。 このため, 次元を増やすと, ある次元まで, 式(1)の第 1 項と第 2 項 の和は減少するが, それ以降は増加し始める。ここでは, どの想定 地震に対しても 3 次元までの計算を実施したが， 2 次元までに最小 值とならない場合は, AIC が増加に転じるまで次元を増やして計算 を実施した。

\section{3 AICに関する計算結果}

図 1 は, 各想定地震について式(1)の計算結果（最小となる AIC） をトレンド関数の次元毎にケース A，B に分けて示したものである。 ここで，式(1) の第 1 項は負の值であり，第 2 項は正の值であるの で, 図中では, それぞれの棒グラフの最小值が第 1 項の值であり, 棒グラフ内の境界線が第 1 項と第 2 項の和である。図 1-(1)は, 高浜 一猿投地震に関する式(1)の計算結果であるが，理論どおり，ケース
A，B ともトレンド関数の次元が大きくなるほど, 式(1)の第 1 項は 小さく, 第 2 項は大きくなっている。第 1 項と第 2 項の和は, ケー ス A ではトレンド関数が 3 次元のとき, ケース $\mathrm{B}$ では 4 次元のと き最小となる。ケース $\mathrm{A}$ よりも $\mathrm{B}$ の方が大きい次元で最小值をと るのは, ケース B の場合, 隣接するボーリング地点間で独立に計算 された地震動パラメタの值に大きな差が生じるケースがあるためで ある。計算された地震動パラメタを忠実に通る補間面を推定する場 合, より高次元のトレンド関数の方が, 式(1)の第 1 項である最尤值 を小さくしや寸い。しかしながら, 連続体である地盤では, 近隣の ボーリング地点での地震動は相互の地点での地震動の影響を受ける ため, 計算値ほど大きな差異は実際には生じない。ケース A では計 算誤差分散を式(11)のように導入することでこの現象を反映させて おり，実現象により近い推定を行っているものと考えられる。情報 量統計の視点からも式(1)によって最小化した AIC は, ケース A の 場合（3 次元のトレンド関数の場合）の方が，ケース B の場合（4 次元のトレンド関数の場合）より 129.3 小さい。AIC では, 同じデ ータに対する複数の確率場モデルを比較する場合, その差が 1 以上 あることを以って有意な差がある ${ }^{9}$ とされていることから，この差 
表 1 (1) 式の計算結果のまとめ

\begin{tabular}{|c|c|c|c|c|}
\hline \multirow{2}{*}{\begin{tabular}{|c|c|} 
表 1 計算結果の \\
まとめ \\
想定地震 \\
\end{tabular}} & \multicolumn{2}{|c|}{$\begin{array}{l}\text { 式(1)を最小とする } \\
\text { トレンド関数の次元数 }\end{array}$} & \multirow[t]{2}{*}{\begin{tabular}{|c|} 
最小 $\mathrm{AIC} の$ \\
差
\end{tabular}} & \multirow[t]{2}{*}{$\begin{array}{l}\text { 相当する } \\
\text { パラメタ数 }\end{array}$} \\
\hline & ケース A & ケース $\mathrm{B}$ & & \\
\hline 高浜－猿投地震 & 3 & 4 & 123.9 & 64 \\
\hline 2 連動地震 & 2 & 3 & 241.1 & 120 \\
\hline 3 連動地震 & 3 & 4 & 156.6 & 78 \\
\hline 過去最大地震 & 2 & 4 & 171.5 & 85 \\
\hline 東側地震 & 1 & 4 & 253.3 & 126 \\
\hline 陸側地震 & 0 & 4 & 239.8 & 119 \\
\hline
\end{tabular}

值 129.3 は非常に大きいと判断できる。129.3 を式(1)の第 2 項のパラ メタの数に置き換えると, $64(\fallingdotseq 129.3 \div 2)$ 個分以上となる。すなわ ち, 計算誤差分散という 1 つのパラメタが, トレンド関数のパラメ 夕 64 個分以上の説明能力を有していることを意味しており, 著者ら が提案した手法（ケースA）が，地震動パラメタの空間分布の確率 場を, 極めて巧みに評価・把握し, 表現していることが分かる。

表 1 は $6 つ の$ 想定地震についての式(1)を最小とするトレンド関数 の次元数, 2 つのケースの最小 AIC の差および相当するパラメタ数 をまとめたものである。2 連動地震以降のいずれの想定地震につい
ても高浜一猿投地震と同様に, 著者らが提案した手法（ケース $\mathrm{A}$ ) は, 一般的なクリギング解析（ケース B) に比べ地震パラメタの空 間分布の確率場を評価するにあたって非常に優れていることが分か る。また, 尾張旭市の近くに震源が位置する高浜一猿投地震の場合 でも, 提案手法では, 式(1)における最適解のトレンド関数の次元は 3 であり, 他の直下型地震に対しても, 3 次元程度のトレンド関数を もって地震動の空間分布を推定できる可能性が高い。

\section{4 レンジに関する計算結果}

図 2 は, 各想定地震に関するレンジをトレンド関数の次元ごとに ケース A, B に分け, (1)から(6)の順に, 高浜一猿投地震, 2 連動地 震, 3 連動地震, 過去最大地震, 東側地震, 陸側地震について示し たものである。図 2-(1)は, 高浜一猿投地震に関するレンジであるが, ケース A のレンジは, ケース B と比較して非常に長い值となってい る。情報量統計の観点から図 1 を見た場合, $「 \sigma_{i}{ }^{2}$ は無視しない方が よりよい推定ができる」と判断できるにも拘らず, 敢えて $\sigma_{c}{ }^{2}=0$ と したケース B は, ケース A と比較してレンジが端的に短くなり, 推 定した確率場がホワイトノイズに近づいていることが分かる。実際 上「ボーリング調查地点直上では誤差なく地震動を推定できる」と は考え難く, すなわち, 地震動 $\mathbf{z}$ の確率場モデルにおいて空間補間 推定を実施する場合,「実際に存在する $\sigma_{i}{ }^{2}$ を反映させた確率モデル」

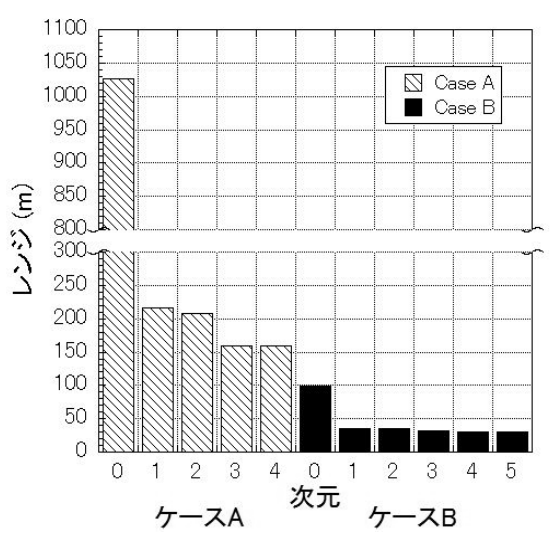

(1) 高浜一猿投地震

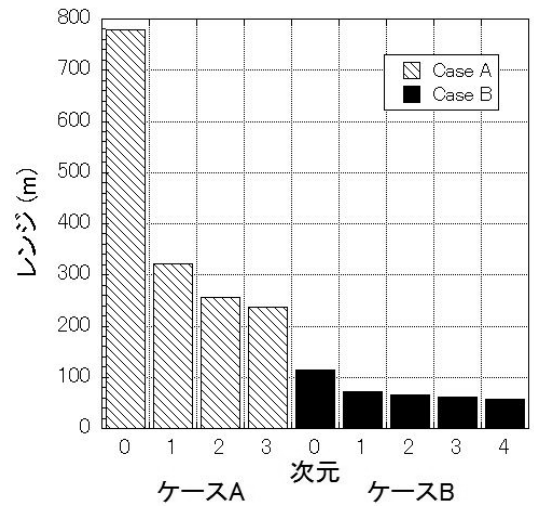

(4) 過去最大地震

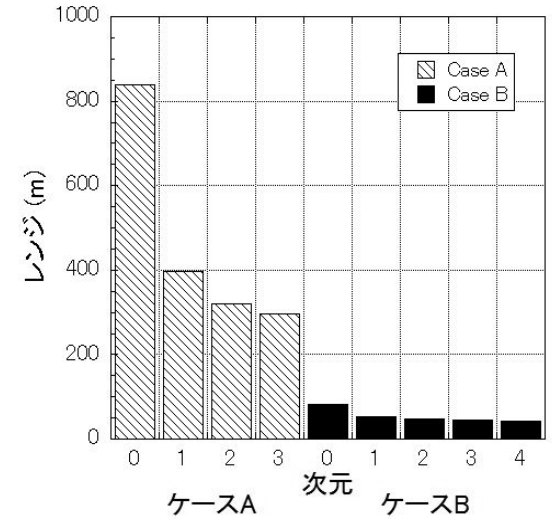

(2) 2 連動地震

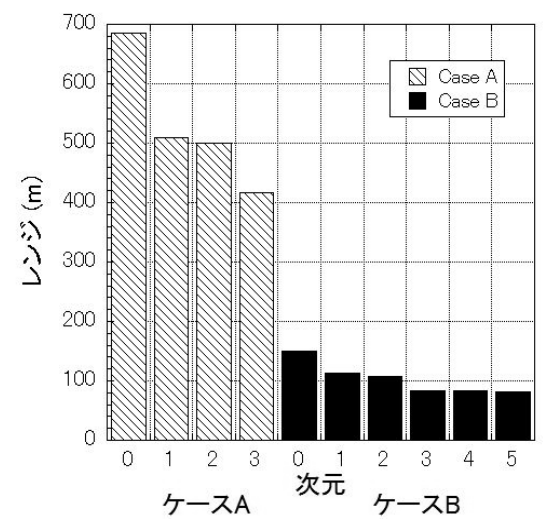

(5) 東側地震

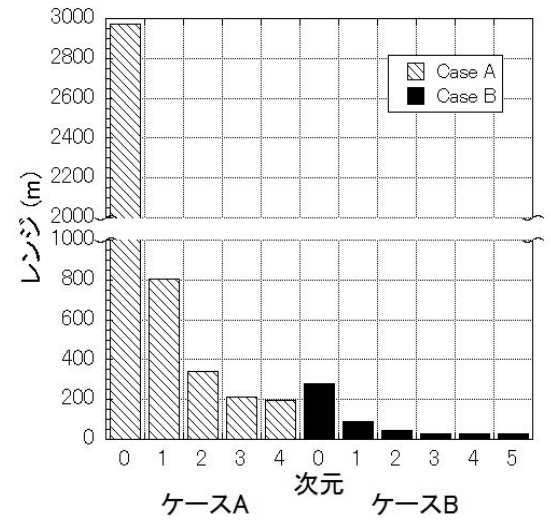

(3) 3 連動地震

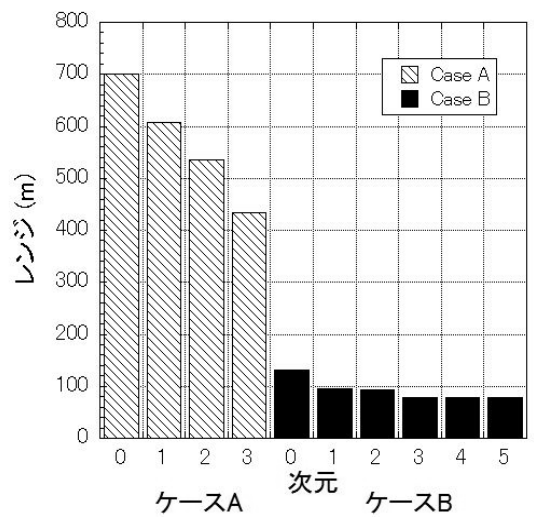

(6) 陸側地震

図 2 尾張旭市における各種震源に対するレンジの計算結果 
を利用する方が現実的であるが, 文献1)でも詳細に議論したように， ケース A の方が実用上も有利であることが分かる。

また，ケース A， B とも，トレンド関数の次元が大きくなるにつ れてレンジが短くなっているが，これは，クリギング解析ではよく 知られた結果である。図1-(1)から, ケース A の場合, トレンド関数 は 3 次元とすることが最適であると判断できるが，この時のレンジ は $158.8 \mathrm{~m}$ である。ケース B の場合, トレンド関数は 4 次元とする ことが最適であると判断できるが，この時のレンジは $30.2 \mathrm{~m}$ である。 ここで, 尾張旭市の面積は約 $21.03 \mathrm{~km}^{2}$ であり, 市内で収集されたボ ーリングデータ数は 676 本であることに注目すると， 1 本のボーリ ングがカバーする平均は $21.03 \times 10^{6} / 676=31,109 \mathrm{~m}^{2}$ であり, 半径約 $100 \mathrm{~m}$ 程度の円の面積に相当する。市内におけるボーリングの調査 地点には, 市の北部約 3 分の 1 の面積を占める森林公園に少なく, 市街地に多いという偏りがあると同時に, 周辺都市である名古屋市, 瀬戸市，長久手市内からもボーリング調査結果を入手している。こ の結果, 建物が少なく, 比較的, 高い推定精度を要求されない地域 で調查地密度が低く, 中心市街地, 住宅地などの高い推定精度が必 要な地域で調查地密度が高いという実用的には有利な偏りがあるう え, ケース A の最適值のレンジ $158.8 \mathrm{~m}$ は, 上記の $100 \mathrm{~m}$ を大きく 超えていることから, 重要地域で高い精度の補間推定が可能である ことが分かる。なお，このように，本推定法の精度を担保するため に必要な標本点（ボーリングデータの数）は，震源からの距離や地
盤の堆積状況に左右されるレンジの大きさに依存するため, 必要な ボーリング密度については場所を特定したうえで議論する必要があ る。一方，ケース B の最適值のレンジ $30.2 \mathrm{~m}$ は，100m に及ばず， 市内の全域を良い精度で補間推定できるとは考え難い。

図 2-(2) (6)は, 順に, 2 連動地震, 3 連動地震, 過去最大地震, 東側地震, 陸側地震に関するレンジを示しているが, これらからも 図 2-(1)と同様の結論を読み取ることができる。

図 1 の最適解に対応するトレンド関数の次元におけるレンジは, 150 から $700 \mathrm{~m}$ 程度であるが, 地盤パラメタの水平方向のレンジが $100 \mathrm{~m}$ 程度 10$)$ であり, 地盤が連続体であると想定できることから妥 当な推定範囲であると考えられる。

\section{5 シルおよび計算誤差分散に関する計算結果}

図 3 は，各想定地震についてシルと計算誤差分散の積み上げグラ フをトレンド関数の次元ごとにケース A，Bに分けて示したもので ある。いずれの想定地震についても, ケース A では, どの次元にお いてもシルに対する計算誤差分散の值は小さい。仮に, この現象が 逆転していれば(シルに対して計算誤差分散值が有為に大きければ), 各ボーリング地点で計算された不充分な推定精度の地震動パラメタ によって, 領域全体の確率場を推定していることとなり, 補間計算 結果は不確かで意味をもたない推定と評価せざる得ないこととなる。 しかしながら，実際には図に示した結果となっており，提案法が，

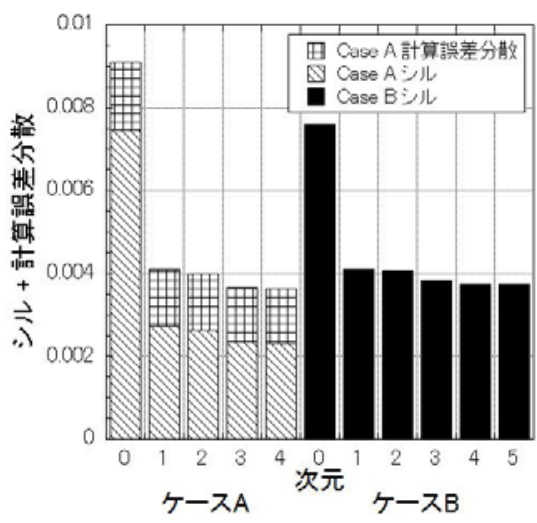

(1) 高浜一猿投地震

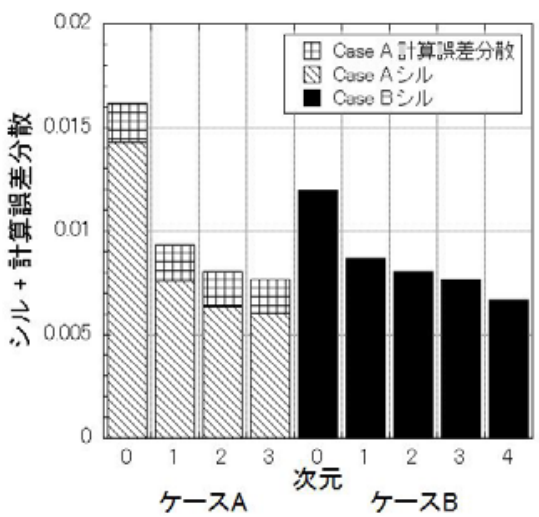

(4) 過去最大地震

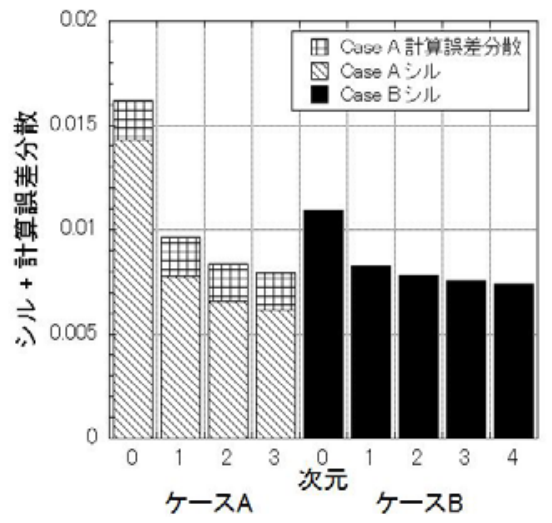

(2) 2 連動地震

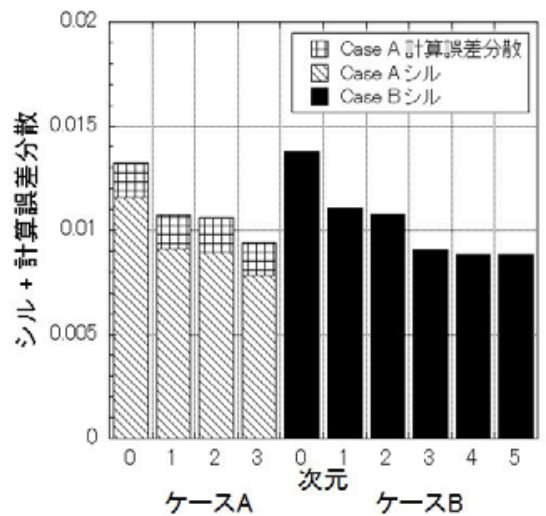

(5) 東側地震

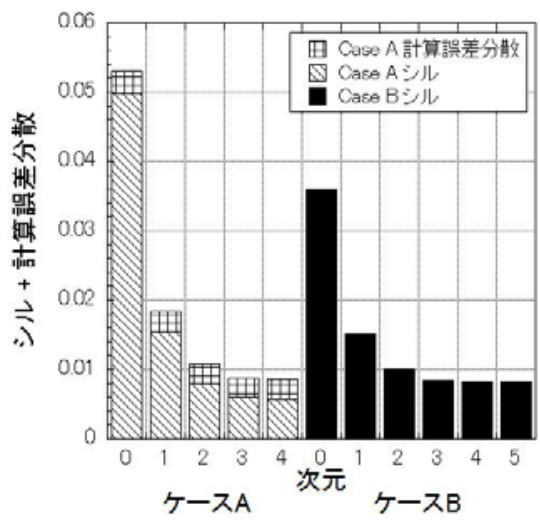

(3) 3 連動地震

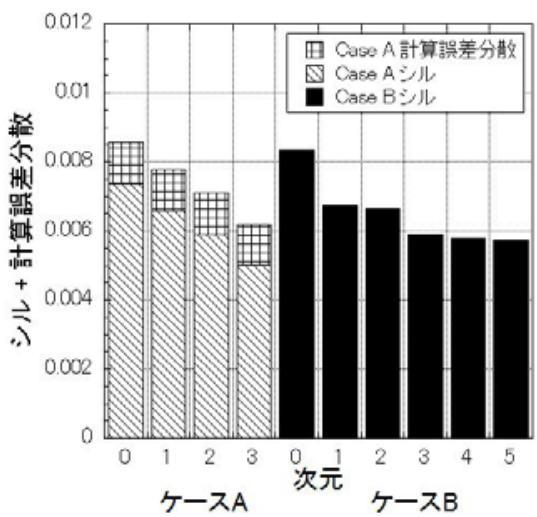

(6) 陸側地震

図 3 尾張旭市における各種震源に対するシルと計算誤差分散の計算結果 
実用に耐えうる推定結果をもたらしているといえる。

一方, AIC が最小となるトレンド関数の次元（表 1 参照）でケー ス Aのシルと計算誤差分散の和と,ケース B のシルを比較すると, これらは同程度であることが分かる。これは, どちらの方法で補間 計算をしても, 補間精度が低くなる地域（ボーリング調查地点が近 隣にない地域）では, 補間推定のおける推定精度に大差がないこと を示している。ケース A と B を比較して, 補間推定精度が高い地域 が，広いか，狭い範囲に限定されるかは，レンジの長さによること になるが，前節で示したように，ケース Aによるレンジの方がケー ス Bによるレンジよりも長く, よって, ケース A のシルと計算誤差 分散の和と, ケース $\mathrm{B}$ のシルが同程度であっても, ケース $\mathrm{A}$ の方 が, より高精度に補間推定できるといえる。

図 1 3 の結果から分かるように, 寸べてのシナリオ地震に対して ケース B よりケース A の方がより優れた確率場モデルである。ケー ス $\mathrm{A}$ において, 最適解のトレンド関数の次元が 0 次となるのは陸側 地震, 1 次となるのは東側地震, 2 次となるのは 2 連動および過去最 大地震， 3 次となるのは高浜一猿投および 3 連動地震であった。0 次となる想定地震のレンジは $699 \mathrm{~m}, 1$ 次の場合は $510 \mathrm{~m}, 2$ 次の場 合は $256 \sim 321 \mathrm{~m}, 3$ 次の場合は 159〜214m であり, 最適解のトレン ド関数の次元順に短くなることと, 次元によって同程度の值をとる ことが分かる。

\section{4. おわりに}

本論文では，著者らが提案した方法でボーリング地点における地 震動パラメタの評価誤差を考慮するクリギング法による統計解析結 果を, 標本点における評価誤差を考慮しない一般的なクリギング法 によるそれと比較しながら, その妥当性, 有用性を検証した。その 結果，1）最小の AIC は一般的なクリギング法よりも提案法の場合 の方が説明変数 $60 \sim 120$ 個程度に相当する $120 \sim 250$ 程度小さくなり 統計学的に有利であることが分かった。また，2）最小の AIC とな る最適解のレンジは, 一般的なクリギング法では, トレンド関数の 次元によって 30〜 80m であるのに対し, 提案法では $150 〜 700 \mathrm{~m}$ と 有為に長く補間推定において非常に有利であること,さらに，3）提 案法におけるシルに対する計算誤差分散は，有為に小さい值にとど まりながら，その和は一般的なクリギング法のシルと同程度である ことが分かった。

提案法はこのような一般的なクリギング法に対して有用である一 方, 必要とする計算はシル, レンジ, 計算誤差分散の 3 つのパラメ 夕の決定と, 最小二乗法によるトレンド関数の決定のみである。

$250 \mathrm{~m}, 50 \mathrm{~m}$ などのメッシュ単位で, 当該メッシュ内, あるいは周辺 にあるボーリングデータから工学的判断に基づいて 1 つ 1 つのッ シュに対する仮想の地盤モデルを作成し，メッシュ単位で地動最大 加速度, 地動最大速度, 計測震度などの地震動強さを推定するこれ までの手法と比較すると, 多数の地盤モデルの想定作業をすべて省 略することができるため, コストの大幅な削減が可能であり, 同時 に客観性の高い推定が可能となる。以上から, 今後, 他の都市への 普及が期待される。

尾張旭市では, 図 1 に示した各シナリオ地震について, 提案法を 用いて地震ハザードを評価し, 建物の重心点ごとに, 地震動パラメ 夕を推定し，これを用いて被害想定を実施しており（個人情報の取
り扱いに対する配慮からホームページ上ではブロッククリギングに よる $50 \mathrm{~m}$ メッシュでの計測地震動と液状化に関するハザードマッ プのみを公開 2) ), 今後も, 市民の移動状沉や, 住宅などの新築, 建 て替え, ボーリングデータの追加など, 八ザードやリスク評価に係 わる情報を, 継続的に更新し, 増加させていく計画である。これと 平行して著者らは, 別途開発した高精度, 低コストの地震計を尾張 旭市内に設置しており，今後も観測情報を活用して地震ハザード評 価の精度向上を進めていく予定である。

\section{謝辞}

本研究は, 平成 23-25 年度日本学術振興会科学研究費 25282100 (基 盤研究(B), 研究代表者 森 保宏) の助成を受けたものです。また, 本研究を実施するに当たり, 尾張旭市からは多大なる協力を頂きま した。ここに，深甚の謝意を表します。

\section{参考文献}

1）菅井径世，森 保宏，小川克郎：クリギング法による地震動分布推定の実 用化に関する研究, 日本建築学会構造系論文集, No. 707, pp.39-46, 2015.1.

2）尾張旭市で予想される地震の予測結果 https://www.city.owariasahi.lg.jp/kurasi/bousai/bousai/owariasahisi deyosousareru.html , 2015.9

3) Krige, D.G.: A statistical approach to some mine valuation and allied problems on the Witwatersrand, Master's thesis, University of Witwatersrand, South Africa, 1951.

4) Matheron, G.: Principles of Geostatistics, Economic Geology, Vol. 58, pp.1246-1266, 1963.

5) Akaike, H.: Information theory and an extension of the maximum likelihood principle, 2nd International symposium on Information Theory, edited by B.N. Petrov and F. Csaki, Akad. Kiado, Budapest, Hungary, pp.267-281,1973.

6) 例えば, Wackernagel, H. 原著: 地球統計学, 地球統計学研究委員会 訳 編／青木謙冶＼cjkstart監訳，森北出版，p.88，2003.

7) 本多眞 : 地質工学における時間及び空間系挙動の確率・統計学的予測に 関寸る研究，清水建設株式会社，ORI，研究報告 00-02，2000。

8）愛知県 防災会議地震部会:平成 23 年度 25 年度 愛知県東海地震 - 東 南海地震・南海地震など被害予測調查結果, 2014.5.

9) 例えば, 坂元慶行, 石黒真木夫, 北川源四郎 著, 北川敏男 編集 : 情 報量統計学 (情報科学講座 $\mathrm{A} \cdot 5 \cdot 4$ ) (情報科学講座), 共立出版, 1983 .

10）松尾 稔：地盤工学一信頼性設計の理念と実際，技報堂出版， 1984.1.

[2015 年 10 月 7 日原稿受理 2016 年 1 月 5 日採用決定］ 